\title{
Serum MMP-9 is elevated in children with asthma
}

\author{
ZHU HONG, YA-MEI LIN, XI QIN and JIANG-LONG PENG \\ Department of Clinical Laboratory, Affiliated Hospital of Hainan Medical College, Haikou, Hainan 571101, P.R. China
}

Received July 27, 2011; Accepted October 19, 2011

DOI: $10.3892 / \mathrm{mmr} .2011 .656$

\begin{abstract}
This study explored the association of matrix metalloproteinase-9 (MMP-9) serum concentration and gene polymorphism with childhood asthma. Serum levels of MMP-9 were determined by sandwich enzyme-linked immunosorbent assay (ELISA) in 65 children with asthma (cases) and 68 healthy children (controls), and the $-1562 \mathrm{C} / \mathrm{T}$ polymorphism in $M M P-9$ was detected by polymerase chain reaction and restriction fragment-length polymorphism (PCR-RFLP) analysis. The results showed that the mean serum levels of MMP-9 in the children with asthma $(136.53 \pm 29.96 \mathrm{ng} / \mathrm{ml})$ were significantly higher than that in the healthy controls $(45.08 \pm 12.53 \mathrm{ng} /$ $\mathrm{ml} ; \mathrm{P}<0.05)$. At $M M P-9$ base position -1562 , the frequencies of the genotypes CC, CT and TT in cases were 67.7, 29.2 and 3.1\% and in controls were 73.5, 25.0 and 1.5\%. The allele frequencies of $\mathrm{C}$ and $\mathrm{T}$ in cases vs. controls were 82.3 and $17.7 \%$ vs. 86.0 and $14.0 \%$, respectively. No statistically significant difference was detected in genotype or allele frequency between these groups. In addition, no significant difference in serum levels of MMP-9 was observed within groups among children with different genotypes $(\mathrm{P}>0.05)$. Therefore, whereas serum levels of MMP-9 are associated with the occurrence of childhood asthma, the MMP-9 $-1562 \mathrm{C} / \mathrm{T}$ gene polymorphism has no correlation with the pathogenesis of childhood asthma.
\end{abstract}

\section{Introduction}

Bronchial asthma (abbreviated asthma) has a complex etiology that remains to be fully understood. A common consequence of asthma is airway remodeling, resulting from irreversible airflow limitation and persistent airway hyper-responsiveness (1). Excess deposition of extracellular matrix (ECM) in the airway wall is a major cause of airway remodeling in asthma, and is closely related to airway wall fibrosis and airflow limitation (2). Matrix metalloproteinases (MMPs) are a zinc- and calcium-dependent endopeptidase

Correspondence to: $\mathrm{Dr}$ Zhu Hong, Department of Clinical Laboratory, Affiliated Hospital of Hainan Medical College, Longhua Road 31, Haikou, Hainan 571102, P.R. China

E-mail: zhu_hong1970@126.com

Key words: matrix metalloproteinase-9, children, asthma, polymorphism superfamily containing proteases able to degrade most ECM components (3). MMP-9 is particularly able to degrade ECM, and has played a role in the pathogenesis of many inflammatory processes (4). Indeed, studies have shown that MMP-9 is closely correlated with airway inflammatory cell migration and airway hyper-responsiveness in an asthmatic rat model (5). Furthermore, polymorphisms in $M M P-9$ have been associated with several diseases, including chronic obstructive pulmonary disease (6). To determine the role of MMP-9 in the pathogenesis of asthma, we compared serum MMP-9 concentrations and frequencies of $M M P-9-1562 \mathrm{C} / \mathrm{T}$ polymorphisms in 65 children with asthma and 68 healthy children.

\section{Patients and methods}

Patients. Sixty-five children with asthma, who had been diagnosed and hospitalized at the Pediatric Clinic of the Affiliated Hospital, Hainan Medical College Hospital between January 2010 and January 2011, participated in the present study (cases). This group included 32 males and 33 females, aged 2-13 years, with a mean age of $8.2 \pm 2.3$. All cases met conventional diagnostic criteria for childhood asthma. The control group was comprised of 68 healthy children from the Physical Examination Center of our hospital, during the same period. This group included 34 males and 31 females, aged 4-14 years, with a mean age of 9.7 \pm 2.7 . No significant differences were observed in age and gender between the two groups of children.

Determination of MMP-9 serum levels. Venous blood samples were collected from all participants. Five milliliters was centrifuged $\left(4^{\circ} \mathrm{C}, 2000 \mathrm{rpm}\right)$, sub-packaged, and cryopreserved at $-20^{\circ} \mathrm{C}$. Serum MMP-9 was measured by sandwich enzymelinked immunosorbent assay (ELISA) using various kits (Bio-Key International Inc., Wall, NJ, USA), according to the manufacturer's instructions. OD values (492 $\mathrm{nm}$ wavelength) were assessed on a microplate reader (BioRad-550).

Detection of the -1562C/T polymorphism of MMP-9. DNA was extracted from peripheral blood according to Lahiri et al (7). Primers for polymerase chain reaction (PCR) included the following: forward, 5'-GCCTGGCACATAGTAGGCCC-3' and reverse, 5'-CTTCCTAGCCAGCCGGCATC-3', which were used for polymorphism detection according to a previous report (8). The reaction mixture (total $50 \mu \mathrm{l}$ ) contained $1.0 \mu \mathrm{g}$ template DNA, $0.2 \mathrm{mM}$ dNTP, $4 \mathrm{U}$ TaqDNA polymerase, $2.0 \mathrm{mM} \mathrm{MgCl} \mathrm{M}_{2}, 1 \mathrm{X}$ PCR buffer, $60 \mathrm{ng}$ forward primer, and 
Table I. The $-1562 \mathrm{C} /$ Tpolymorphism of the $M M P-9$ gene in the case and control groups.

\begin{tabular}{lcccccc}
\hline \multirow{2}{*}{ Group } & $\mathrm{n}$ & \multicolumn{3}{c}{ Genotype $^{\mathrm{a}} \mathrm{n}(\%)$} & & \multicolumn{2}{c}{ Gene frequency $^{\mathrm{b}} \mathrm{n}(\%)$} \\
\cline { 3 - 5 } & & $\mathrm{CC}$ & $\mathrm{CT}$ & $\mathrm{TT}$ & $\mathrm{C}$ & $\mathrm{T}$ \\
\hline Case group & 65 & $44(67.7)$ & $19(29.2)$ & $2(3.1)$ & $107(82.3)$ & $23(17.7)$ \\
Control group & 68 & $50(73.5)$ & $17(25.0)$ & $1(1.5)$ & $117(86.0)$ & $19(14.0)$ \\
Total & 133 & $94(70.7)$ & $36(27.1)$ & $3(2.3)$ & $224(84.2)$ & $42(15.8)$ \\
\hline
\end{tabular}

${ }^{\mathrm{a}} \chi^{2}=0.760, P=0.684 ;{ }^{\mathrm{b}} \chi^{2}=0.692, \mathrm{P}=0.405 ; \mathrm{OR}=0.755,95 \%$ CI: $0.390-1.464$.

60 ng reverse primer. Cycling conditions were as follows: predenaturation at $95^{\circ} \mathrm{C}$ for $5 \mathrm{~min}$; denaturation at $94^{\circ} \mathrm{C}$ for $1 \mathrm{~min}$, annealing at $63^{\circ} \mathrm{C}$ for $1 \mathrm{~min}$ and extension at $74^{\circ} \mathrm{C}$ for $1 \mathrm{~min}, 30$ cycles total; and final extension at $72^{\circ} \mathrm{C}$ for $10 \mathrm{~min}$. Amplified products were resolved in $2 \%$ agarose gel. Restriction digestion was performed on $15 \mu \mathrm{l}$ PCR with $5 \mathrm{U}$ SphI (MBI product) at $37^{\circ} \mathrm{C}$ for $16 \mathrm{~h}$. Restriction fragments were resolved in $2 \%$ agarose gel.

Statistical methods. SPSS 13.0 statistical software was used to analyze data. Single-factor analysis of variance was used to compare MMP-9 serum levels between the groups. The $\chi^{2}$ and t-test were used to compare genotypes and gene frequencies. All analyses were two-sided tests, and $\alpha=0.05$ was considered statistically significant.

\section{Results}

Serum MMP-9 levels in children with asthma. Mean MMP-9 serum levels were $136.53 \pm 29.96 \mathrm{ng} / \mathrm{ml}$ in the children with asthma and $45.08 \pm 12.53 \mathrm{ng} / \mathrm{ml}$ in the healthy children (Fig. 1). This difference in circulating MMP-9 was statistically significant $(\mathrm{t}=23.139, \mathrm{P}<0.001)$, indicating that MMP-9 was highly expressed in children with asthma.

The $-1562 C / T$ polymorphism of MMP-9 in children with asthma. As expected, PCR-RFLP produced 2 bands (194 and $242 \mathrm{bp}$ ) for the TT genotype, 3 bands $(436,194$, and $242 \mathrm{bp})$ for the heterozygous TC genotype, and 1 band (436 bp) for the CC genotype (Fig. 2). As shown in Table I, genotype frequencies for $M M P-9-1562 \mathrm{C} / \mathrm{T}$ were $67.7 \mathrm{CC}, 29.2 \mathrm{CT}$, and $3.1 \% \mathrm{TT}$ for cases and $73.5 \mathrm{CC}, 25.0 \mathrm{CT}$, and $1.5 \% \mathrm{TT}$ for controls. These genotype distributions were not significantly different, suggesting that polymorphism at MMP-9 base position -1562 are not associated with asthma. Similarly, allele frequencies of $\mathrm{C}$ and $\mathrm{T}$ at MMP-9 -1562 were 82.3 and $17.7 \%$, respectively, in the cases, 86.0 and $14.0 \%$, respectively, in the controls. Again, these frequencies were not significantly different between the groups, with the relative risk odds ratio equal to $0.755(95 \%$ confidence interval: 0.390-1.464).

MMP-9 serum levels by MMP-9 genotype. To determine whether the MMP-9 genotype was associated with higher levels of circulating MMP-9 in children with asthma, we assessed serum MMP-9 according to genotype within each group (cases and controls). In children with asthma, mean

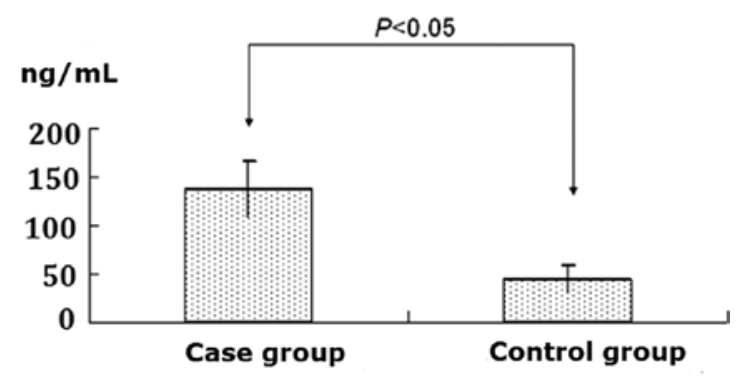

Figure 1. The serum levels of MMP-9 in the case and control groups.

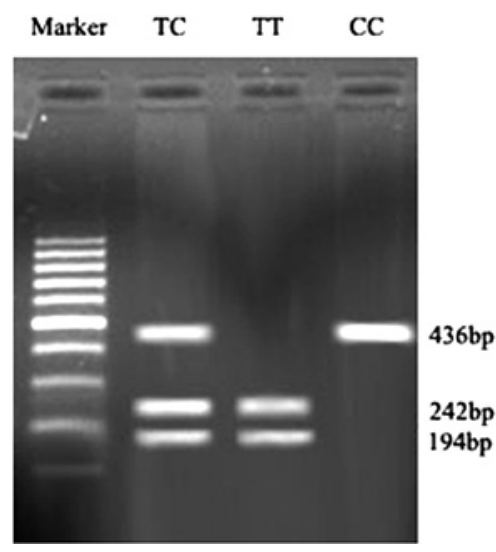

Figure 2. The electrophoretogram of the $-1562 \mathrm{C} / \mathrm{T}$ polymorphism of the $M M P-9$ gene.

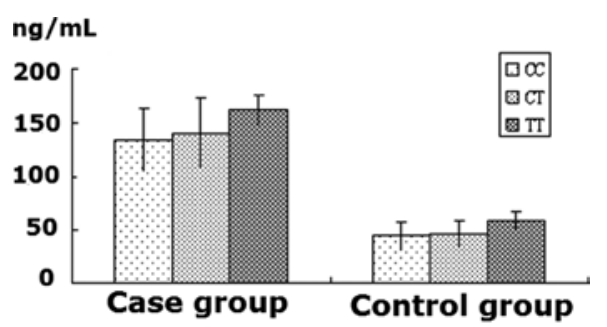

Figure 3. The serum levels of MMP-9 in children with different genotypes.

circulating MMP-9 levels were $133.59 \pm 29.50 \mathrm{ng} / \mathrm{ml}$ for the CC genotype, $140.67 \pm 31.52 \mathrm{ng} / \mathrm{ml}$ for the CT genotype, and $161.56 \pm 13.69 \mathrm{ng} / \mathrm{ml}$ for the TT genotype (Fig. 3); these 
differences were not statistically significant. In the healthy children, mean circulating MMP-9 levels were 44.22 \pm 12.721 , $46.08 \pm 11.90$ and $58.46 \pm 7.94 \mathrm{ng} / \mathrm{ml}$ for the CC, CT, and TT genotypes, respectively; these differences were not statistically significant. These findings suggest that the -1562 polymorphism at MMP-9 does not affect circulating MMP-9 protein levels.

\section{Discussion}

MMP-9 identified in 1974 by Sopata and Dancewicz (9), has been associated with many disease processes, including those of respiratory diseases. MMPs, particularly MMP-9, break down most components of the extracellular matrix (ECM) (3) by degrading structural proteins such as collagen and elastin. MMP-9 is believed to play an important role in airway remodeling in chronic airway diseases, including asthma $(10,11)$. Indeed, studies have shown that MMP-9 expression is closely related to the severity of asthma (12).

In the present study, we assessed expression levels of MMP-9 in 65 children with asthma and 68 healthy children. Notably, we observed significantly higher circulating levels of MMP-9 in children with asthma. To determine whether polymorphisms in the MMP-9 gene are also associated with the pathogenesis of asthma, we investigated $M M P-9$ genotypes for a previously identified SNP, $-1562 \mathrm{C} / \mathrm{T}$, in our study populations. However, we did not detect any significant differences in either the MMP-9 genotypes or allele frequencies for this polymorphic locus between children with asthma and healthy control individuals. Moreover, MMP-9 serum levels were not associated with particular genotypes. These findings suggest that, while circulating levels of MMP-9 are higher in children with asthma, polymorphisms at position -1562 in the gene are neither responsible for increased production of MMP-9 nor associated with the pathogenesis of asthma. Thus, the increased production of MMP-9 appears to be related to the inflammatory process of asthma, but is likely stimulated by other genes in the process.

In conclusion, while the etiology of asthma remains to be fully elucidated, MMP-9 plays a role in its pathogenesis (13). We found that children with asthma exhibit increased levels of MMP-9 in the serum. The lack of correlation between MMP-9 genotype and either asthma incidence or circulating MMP-9 levels indicates that further studies are required to identify the genetic components affecting MMP-9 expression.

\section{References}

1. Tagaya $\mathrm{E}$ and Tamaoki J: Mechanisms of airway remodeling in asthma. Allergol Int 56: 331-340, 2007.

2. Araujo BB, Dolhnikoff M, Silva LF, Elliot J, Lindeman JH, Ferreira DS, Mulder A, Gomes HA, Fernezlian SM, James A and Mauad T: Extracellular matrix components and regulators in the airway smooth muscle in asthma. Eur Respir J 32: 61-69, 2008.

3. Donadio AC, Remedi MM, Susperreguy S, Frede S, Gilardoni MB, Tang Y, Pellizas CG and Yan L: Extracellular matrix metalloproteinase inducer (EMMPRIN) and matrix metalloproteinases (MMPs) as regulators of tumor-host interaction in a spontaneous metastasis model in rats. Histochem Cell Biol 130: 1155-1164, 2008.

4. Swarnakar S, Paul S, Singh LP and Reiter RJ: Matrix metalloproteinases in health and disease: regulation by melatonin. J Pineal Res 50: 8-20, 2011.

5. Liu WJ, Liang ZP, Chen ZY, Qin G, Huang Y and Li WR: Role and mechanism of the expression of matrix metalloproteinase 9 and tumor necrosis factor $\alpha$ in upper and lower respiratory tract inflammation in rats. Zhonghua Er Bi Yan Hou Tou Jing Wai Ke Za Zhi 46: 325-330, 2011.

6. Lee SY, Kim MJ, Kang HG, Yoo SS, Choi YY, Lee WK, Cha SI, Kim CH, Jung TH and Park JY: Polymorphisms in matrix metalloproteinase-1, -9 and -12 genes and the risk of chronic obstructive pulmonary disease in a Korean population. Respiration 80: 133-138, 2010.

7. Lahiri DK and Schuabel B: DNA isolation by a rapid method from human blood: Effect of $\mathrm{MgCl}_{2}$, EDTA, storage time, and temperature on DNA yield and quality. Biochem Genet 31: 321-328, 1993.

8. Ganter K, Deichmann KA and Heinzmann Al: Association study of polymorphisms within matrix metalloproteinase 9 with bronchial asthma. Int J Immunogenet 32: 233-236, 2005.

9. Sopata I and Dancewicz AM: Presence of a gelatin-specific proteinase and its latent form in human leukocytes. Biochim Biophys Acta 370: 510-523, 1974.

10. Pinto LA, Depner M, Klopp N, Illig T, Vogelberg C, von Mutius E and Kabesch M: MMP-9 gene variants increase the risk for nonatopic asthma in children. Respir Res 11: 23, 2010.

11. Bourboulia D and Stetler-Stevenson WG: Matrix metalloproteinases (MMPs) and tissue inhibitors of metalloproteinases (TIMPs): positive and negative regulators in tumor cell adhesion. Semin Cancer Biol 20: 161-168, 2010.

12. Todorova L, Bjermer L, Miller-Larsson A and WestergrenThorsson G: Relationship between matrix production by bronchial fibroblasts and lung function and AHR in asthma. Respir Med 104: 1799-1808, 2010.

13. Tang LF, Du LZ, Chen ZM and Zou CC: Levels of matrix metalloproteinase-9 and its inhibitor in bronchoalveolar lavage cells of asthmatic children. Fetal Pediatr Pathol 25: 1-7, 2006. 